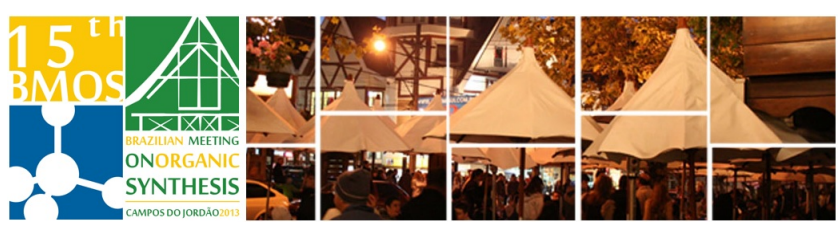

\title{
Study of $\mathrm{NH}_{4}\left[\mathrm{NbO}\left(\mathrm{C}_{2} \mathrm{O}_{4}\right)_{2}\left(\mathrm{H}_{2} \mathrm{O}\right)\right] . \mathrm{n} \mathrm{H}_{2} \mathrm{O}$ as a catalyst in transesterification of soybean oil to produce Biodiesel
}

\section{Bruno Henrique Arpini, Johann Castro Sodré Sunderhus, Valdemar Lacerda Jr.*, Sandro José Greco, Álvaro Cunha Neto and Reginaldo Bezerra dos Santos}

Laboratório de Síntese Orgânica e Medicinal - LSO\&M, Departamento de Química, Centro de Ciências

Exatas, Universidade Federal do Espírito Santo, Vitória-ES, Brazil. *e-mail: vljuniorqui@gmail.com

Keywords: Catalyst, Biodiesel, Niobium Ammonium Oxalate.

\section{INTRODUCTION}

Transesterification is the predominant process in the conversion of vegetable oils into biodiesel fuel. In this process, triglycerides are reacted with an alcohol, ethanol or methanol, and catalyst or base. ${ }^{1}$

Niobium materials are presently of great interest in heterogeneous catalysis where they are used as catalyst active ingredient, carrier or auxiliary agent ${ }^{2}$, ${ }^{3}$. Ammonium niobium oxalate is an excellent watersoluble complex. It is insensitive to moisture and easily handled in ambient atmosphere. ${ }^{4}$ In this study are shown the results of using ammonium niobium oxalate as a catalyst to prepare biodiesel.

\section{RESULTS AND DISCUSSION}

The reactions were made with the addition of ethanol $(1.0 \mathrm{ml})$, soybean oil $(0.5 \mathrm{~g})$, DMSO $(2.5 \mathrm{ml})$ as solvent to increase the boiling point of the mixture, and the catalyst in the proportions shown in Table 1. One reaction was made without the use of catalysts.

The reactions were made under heating conditions of $25^{\circ} \mathrm{C}$ and $80^{\circ} \mathrm{C}$ in a reflux system, and the reaction time ranged from 4 to 48 hours. For the reactions of $24 \mathrm{~h}$ and $48 \mathrm{~h}, 0.5 \mathrm{~mL}$ of ethanol were added every 8 hours. After the end of the reaction time, the products went through multiple extractions. Through the use of ${ }^{1} \mathrm{H}-\mathrm{NMR}$ spectroscopy the products obtained were analyzed and quantified by the follow expression:

$$
\text { Conversion rates }(\%)=\frac{\mathrm{Ab}}{\mathrm{A} 0+\mathrm{Ab}} \times 100 \%
$$

Such expression relates the area of integration of the signal referring to the ethoxy hydrogen's ester (Ab) and the area of integration of the signal referring to methylene hydrogen's glyceride (Ao) from triglyceride.

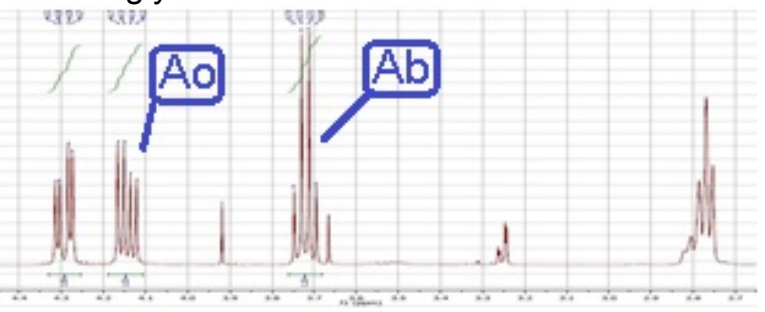

Figure 1. Methylene hydrogen's of the triglyceride (Ao) and ethoxy hydrogen's ester of the biodiesel (Ab). $15^{\text {th }}$ Brazilian Meeting on Organic Synthesis - $15^{\text {th }}$ BMOS - November 10-13, 2013 - Campos do Jordão, Brazil
Table 1. Time, temperature, proportions and conversion rates for each products.

\begin{tabular}{|c|c|c|c|}
\hline Time & Temperature & $\begin{array}{c}\text { Cat/Oil(m/m) } \\
\%\end{array}$ & $\begin{array}{c}\text { Conversion } \\
\text { rates (\%) }\end{array}$ \\
\hline \multirow{2}{*}{$4 h$} & $25^{\circ} \mathrm{C}$ & $\begin{array}{c}20 \% \\
100 \%\end{array}$ & $\begin{array}{l}16.0 \% \\
17.4 \%\end{array}$ \\
\hline & $80^{\circ} \mathrm{C}$ & $\begin{array}{l}20 \% \\
100 \%\end{array}$ & $\begin{array}{l}16.7 \% \\
17.4 \%\end{array}$ \\
\hline \multirow{2}{*}{$24 \mathrm{~h}$} & $25^{\circ} \mathrm{C}$ & $\begin{array}{c}20 \% \\
100 \%\end{array}$ & $\begin{array}{l}20.1 \% \\
28.6 \%\end{array}$ \\
\hline & $80^{\circ} \mathrm{C}$ & $\begin{array}{l}20 \% \\
100 \%\end{array}$ & $\begin{array}{l}38.7 \% \\
54.5 \%\end{array}$ \\
\hline \multirow{2}{*}{$48 \mathrm{~h}$} & $25^{\circ} \mathrm{C}$ & $\begin{array}{c}20 \% \\
100 \%\end{array}$ & $\begin{array}{l}27.4 \% \\
38.3 \%\end{array}$ \\
\hline & $80^{\circ} \mathrm{C}$ & $\begin{array}{l}20 \% \\
100 \%\end{array}$ & $\begin{array}{l}50.3 \% \\
71.2 \%\end{array}$ \\
\hline
\end{tabular}

The increase in conversion rates is related to the increase in time, temperature and mass ratio of Ammonium Niobium Oxalate, because there is increased availability in the reaction.

\section{CONCLUSION}

We found that the use of Ammonium Niobium Oxalate as a catalyst promotes higher conversions in the transesterification of soybean oil in very satisfactory yields. The best conversion rate $(71.2 \%)$ was the reaction using Ammonium Niobium Oxalate under condition of $80{ }^{\circ} \mathrm{C}$ and the proportion of $100 \%$ [(Cat/Oil).100\%] for 48 hours.

\section{ACKNOWLEDGEMENTS}

The authors thanks to CBMM, CAPES, CNPq, and LabPetro-DQUI/UFES.

\section{REFERENCES}

1 Soldi, R.; Oliveira, A.; Ramons, L. e César-Oliveira M. A. Appl Catal. A: Gen. 2009, 361, 42-48.

${ }^{2}$ Nowak I.; Ziolek M.; Niobium compounds: preparation, characterization, and application in heterogeneous catalisys. Chem Rev. 1999; 99:3603-24. ${ }^{3}$ Arpini, H. B.; Lacerda Jr., V.; dos Santos, D. A.; dos Santos, R. B.; Greco, S. J; Neto, Á. C.; 35 RASBQ, Resumos, TEC 008, 2013.

${ }^{4}$ Su, T. T.; Zhai, H. J.; Gong, H. Studies on termal decomposition kinetics and mechanism of ammonium niobium oxalate. J. Therm. Anal. Calorim. 2009, 98, 449-45 